\title{
A Rare Variation of the Testicular Blood Supply by the Deferential Artery
}

\author{
Rara Variación del Suministro de Sangre Testicular por la Arteria del Conducto Deferente
}

\author{
Yong Zheng*; Qianqian Yuan*; Xin He* \& Yueshan Lei"
}

ZHENG, Y.; YUAN, Q.; HE, X. \& LEI, Y. A rare variation of the testicular blood supply by the deferential artery. Int. J. Morphol., 34(3):950952, 2016.

SUMMARY: Any compression of testicular arteries may lead to loss of spermatogenesis and gonadal hormone production, existence of the variational arteries is accountable in cases of vasoligation, orchidopexy and other surgical approach on them. Anomalies of the testicular blood arteries were observed during dissection of the pelvic cavity in a 68-year-old male cadaver. This report describes a very rare case of lack of testicular arteries. For the blood supply to the testis, thick deferential arteries form some vascular winding and loops and course accompanied by deferent duct to the testis. This case report would serve as ray of light for knowledge of the possible variations of the testicular arteries during surgical procedures.

KEY WORDS: Deferential artery; Variation; Umbilical artery.

\section{INTRODUCTION}

Because of the importance in testicular physiology, testicular and renal surgery, anatomy of the testicular blood supply arteries should be studied intensively. The deferential arteries could play an important role in regulating flow or pressure of blood that arrives to the testis (Medina et al., 1996). It is a long, slender vessel and usually originates in the inferior vesical artery and accompanies the ductus deferens as far as the testis. Along its course, it gives several branches to supply the entire length of the ductus deferens, the cauda and corpus epididymidis.

The developmental origins of testicular arteries are very complex. In general, the testis mainly receives its blood supply from the testicular artery which is essential for the efficient functioning of the testis (Mostafa et al., 2008). In the present study we reported unusual arteries of the supply for the testis, the bilateral deferential arteries with winding course are the main blood supply to the testis. To the best of our knowledge, this is the first report on such a variation.

\section{CASE REPORT}

During routine dissection of a cadaver during the Human Body Course, a rare variation in the origin and course of the deferential artery was observed. The variation was found in the cadaver of a 68 -year-old man who donated his body through the body donation program (Fig. 1). The left deferential artery originated from an anterior trunk of the left internal iliac artery. At the beginning of the left deferential artery, the diameter was $1.2 \mathrm{~mm}$. On its course, the deferens duct artery gave off a left superior vesical artery at $5.5 \mathrm{~cm}$ from the origin. After the bifurcation, the diameter of the left deferens duct artery was $0.8 \mathrm{~mm}$ (Fig. 2).

The right deferential artery and superior vesical artery respectively originated from the initial segment of right umbilical artery, an anterior trunk of the right internal iliac artery. The diameter of the right deferens duct artery was $1.4 \mathrm{~mm}$ (Fig. 2). The deferens duct arteries formed some vascular winding and loops and course accompanied by deferent duct. Until the deep inguinal ring, the left and right deferens duct artery was 13.2 and $12.5 \mathrm{~cm}$ in length, respectively (Figs. 1 and 2 ).

\section{DISCUSSION}

The deferential artery is one of the supplying arteries of testis. It is reported that the diameter of the artery's cast 


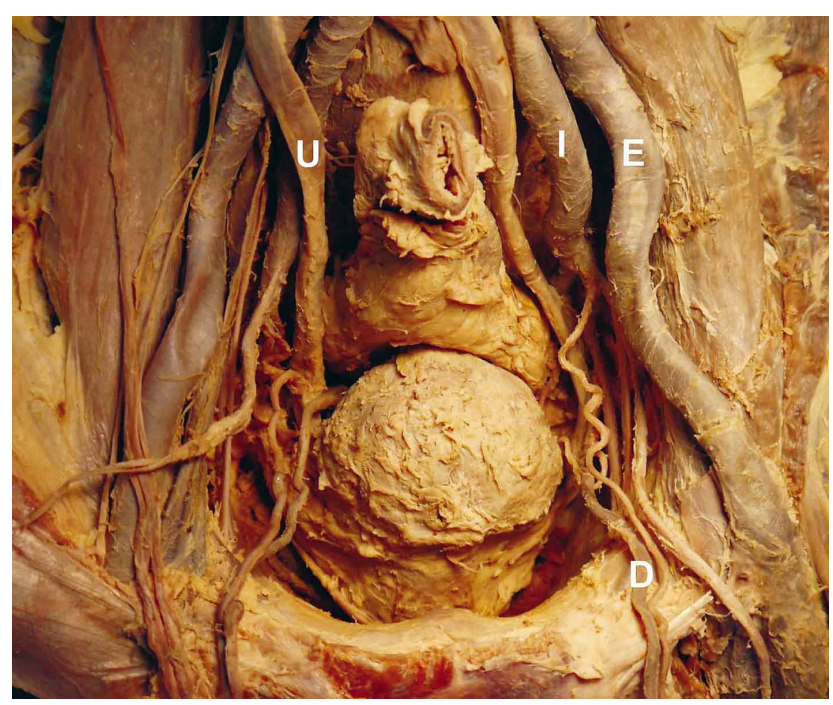

Fig. 1. Overview of the pelvis. E= external iliac artery; I= Internal iliac artery; $\mathrm{D}=$ deferent duct; $\mathrm{U}=$ Ureter.

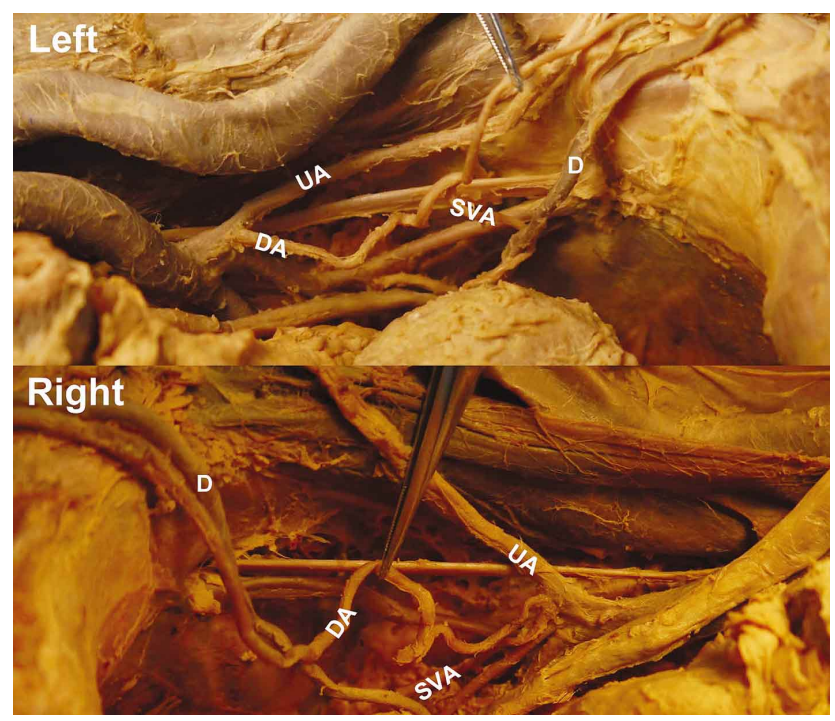

Fig. 2. Photograph of the deferential arteries. The left deferential artery (upper panel) arose from the initial the origin of left umbilical artery. The right deferential artery (lower panel) arose from initial segment of right umbilical artery. $\mathrm{D}=$ deferent duct; $\mathrm{UA}=$ umbilical artery; $\mathrm{DA}=$ deferential artery; $\mathrm{SVA}=$ superior vesical artery.

fitted in the ranges $0.6-1.1 \mathrm{~mm}$, and the course of the artery was almost straight (Polguj et al., 2010). In the present case, we found the bilateral deferential arteries are with larger diameter and winding course. Although some scientists suggested that collateral blood flow through the cremasteric and deferential arteries is ineffective in cases of testicular artery ligation (Raman \& Goldstein, 2004), the anastomotic channels between the testicular artery and deferential artery have been demonstrated by dissection and radiographic studies (Mostafa et al.; Polguj et al.,). For the abdominal testis, the collateral blood supply may be based mainly on the deferential artery, the fetal testes were supplied by only testicular artery and deferential artery in the abdomen (Sampaio et al., 1999). Especially, it is reported that the viability of the testis depends on the collateral deferential artery blood supply after Fowler Stephens orchiopexy (Yalcin et al., 2005). So, the blood supply by the deferential artery is critical for the functioning of the testis.

The anomalies of the testicular blood arteries include variations of their origin; course and number is very complex (Xue et al., 2005). There are numerous reports about variations in the origin and course of the testicular artery (Singh et al., 2011; Mao \& Li, 2015; Mamatha et al., 2015 ). It is noteworthy in this case that the deferential arteries are the main blood supply to the testis is rather rare. Knowledge of the origin and course of testicular blood vessels is important, not only from a developmental standpoint, but also from a physiological function prospective. The variation is especially significant in avoiding the complications in clinical examination and surgical approaches in abdominal region, and has a sound anatomical basis for surgical procedures involving division of the testicular blood artery. Therefore, considering to characterize the vascular anatomy and reduce the chances of collateral injures, the case is reported.

\section{ACKNOWLEDGMENTS}

This work was supported by a grant from the Undergraduates Innovation Research Program of Wuhan University School of Medicine (Grant No: MS2015003).

ZHENG, Y.; YUAN, Q.; HE, X. \& LEI, Y. Rara variación del suministro de sangre testicular por la arteria del conducto deferente. Int. J. Morphol., 34(3):950-952, 2016.

RESUMEN: Cualquier compresión de las arterias testiculares puede conducir a la pérdida de la espermatogénesis y la producción de hormonas gonadales. La existencia de variaciones en las arterias testiculares es relevante en los casos de vasectomía, orquidopexia y otros tipos de abordaje quirúrgico. Se observaron anomalías de las arterias testiculares durante la disección de la cavidad pélvica de un cadáver de sexo masculino de 68 años de edad. En este trabajo se describe un caso muy poco frecuente de ausencia de arterias testiculares. Para el suministro sanguíneo del testículo, se encontraron arterias deferentes gruesas que producen sinuosidad y tortuosidad vascular junto al conducto deferente en los testículos. Este caso podría ser útil para el conocimiento de las posibles variaciones de las arterias testiculares durante los procedimientos quirúrgicos.

PALABRAS CLAVE: Arteria deferente; Variación; Arteria umbilical. 


\section{REFERENCES}

Mamatha, H.; D'Souza, A. S.; P. V.; Ray, B.; Suhani \& Pallavi. A cadaveric study about the anomolous origin of testicular arteries arising from the accessory renal arteries. Indian J. Surg., 77(2):111-6, 2015

Mao, Q. H. \& Li, J. An accessory renal artery originating from the testicular artery, a rare variant. Indian J. Surg., 77(6):549-50, 2015.

Medina, P.; Chuan, P.; Noguera, R.; Vila, J. M.; Aldasoro, M. \& Lluch, S. Reactivity of human deferential artery to constrictor and dilator substances. J. Androl., 17(6):733-9, 1996.

Mostafa, T.; Labib, I.; El-Khayat, Y.; El-Rahman El-Shahat, A. \& Gadallah, A. Human testicular arterial supply: gross anatomy, corrosion cast, and radiologic study. Fertil. Steril., 90(6):2226$30,2008$.

Polguj, M.; Jedrzejewski, K. S. \& Topol, M. Arterial supply of human and bovine testes: a topographic and morphometric comparison study. Folia Morphol. (Warsz.), 69(4):225-31, 2010 .

Raman, J. D. \& Goldstein, M. Intraoperative characterization of arterial vasculature in spermatic cord. Urology, 64(3):561-4, 2004.

Sampaio, F. J.; Favorito, L. A.; Freitas, M. A.; Damião, R. \& Gouveia, E. Arterial supply of the human fetal testis during its migration. J. Urol., 161(5):1603-5, 1999.

Singh, R.; Jaiswal, A.; Shamal, N. S. \& Singh, S. P. Variation in the origin of the testicular arteries and drainage of the right testicular vein. Int. J. Morphol., 29(2):614-6, 2011.

Xue, H. G.; Yang, C. Y.; Ishida, S., Ishizaka, K.; Ishihara, A.; Ishida A. \& Tanuma, K. Duplicate testicular veins accompanied by anomalies of the testicular arteries. Ann. Anat., 187(4):393-8, 2005.

Yalcin, B.; Komesli, G. H.; Ozgök, Y. \& Ozan, H. Vascular anatomy of normal and undescended testes: surgical assessment of anastomotic channels between testicular and deferential arteries. Urology, 66(4):854-7, 2005.

\author{
Correspondence to: \\ Dr. Yueshan Lei, PhD \\ Department of Anatomy and Embryology \\ Wuhan University School of Basic Medical Sciences \\ Wuhan University \\ 185 Donghu Road, Wuhan \\ Hubei 430071 \\ CHINA
}

Tel: +86 2768759697

Fax: +86 2768758766

Email: leiys2016@outlook.com

Received: 06-05-2016

Accepted: 05-07-2016 